\title{
Screening of phytopathogens and phytopathoges on Chenomeles (CHAENOMELES LINDL.) cultivars
}

\author{
$Y$. Fedulova ${ }^{1}, A$. Kuklina $^{2}, V$. Sorokopudov $^{3}, O$. Sorokopudova $^{3}, S$. Shlapakova ${ }^{4, *}$, and $Y$. Lukashov ${ }^{4}$ \\ ${ }^{1}$ Michurinsk State Agrarian University, Michurinsk 393760, Russia \\ ${ }^{2}$ N.V. Tsitsin Main Botanical Garden of RAS, Moscow 127276, Russia \\ ${ }^{3}$ All-Russian Horticultural Institute for Plant-Breeding, Agrotechnology and Nursery, Moscow 115598, Russia \\ ${ }^{4}$ Bryansk State Engineering Technological University, Bryansk 241037, Russia
}

\begin{abstract}
The pathogenic microflora and entomofauna were studied on the Chaenomeles Lindl. cutivars (Maloideae, Rosaceae). In central Russia, the multi-year systematic monitoring of pathogens and phytophages was carried out on plants Ch. japonica, Ch. cathayensis, Ch. $\times$ superba. Among the identified pathogens, the micromycetes belonging to genera Botrytis, Cytospora, Diplocarpon, Entomosporium, Gloeosporium, Monilia, Neonectria, Penicillium, Pestalotia, Phomopsis, Phyllosticta, Septoria and Sphaeropsis were found to be injurious. With age, the accumulation of infectious background, including viral diseases and the damaging entomofauna was noted in the plantings of fruit crop Chaenomeles. The species composition of phytophages is mainly represented by autochthonous species (polyphages and oligophages), preferring the plants of Rosaceae family. Despite the abundance of species in the phytophage complex, it has a little effect on the decorativeness of Ch. japonica, Ch. cathayensis and Ch. $\times$ superba.
\end{abstract}

\section{Introduction}

The species of genus Chaenomeles Lindl. (Maloideae, Rosaceae) come from Japan and China and are valued in decorative gardening. Such cultivars as Ch. speciosa (Sweet) Nakai, Ch. cathayensis (Hemsl.) C.K. Schneid., Ch. japonica (Thunb.) Lindl. ex Spach, as well as garden hybrids - Ch. $\times$ superba $($ Frahm) Rehder (Ch. japonica $\times$ Ch. speciosa) and others [1,2] were used to obtain flowering varieties.

In the climatic conditions of Russia, the most stable species is Ch. japonica (Thunb.) Lindl. ex Spach. This species is interesting for its highly vitaminized, fragrant fruits and it attracts attention of foreign [3] and Russian [4-8] breeders.

Although it is believed that Chaenomeles species are disease-resistant, it is known from the literature that, in China, the representatives of genera Phoma sp. and Phyllosticta sp. [9] settle on these plant bushes. Many pathogens were found on Chaenomeles plant species surfaces in Europe [3] and those of Aphis pomi in Iran [10].

The purpose of this study was to research and identify representatives of pathogenic microflora and harmful entomofauna on the Chaenomeles cultivars in the regions of central Russia.

\section{Material and method}

The study of phytopathogens and phytophages on the Chaenomeles cultivars was carried out in the Tambov region, Moscow region and in the arboretum of N.V. Tsitsin Main Botanical Garden.

In 2007-2009, the endophytic microflora was tested on the cultivars, forms and types of Ch. japonica and $C h$. Cathayensis in the Tambov region. Crops taken from annual shoots were placed in sterile tubes and Petri dishes with 2 variants of nutrient media from agar-agar $(15 \mathrm{~g})$ : in the $1^{\text {st }}$ variant - with intoxicating (hop) wort (1 1$)$, in the $2^{\text {nd }}-$ with potato $(11)$.

The analysis and registration of fungal and bacterial microflora colonies was carried out under the microscope "Biomed-4" and expressed in (\%) of the total number of tests [1].

In 2010-2017, the monitoring, including the analysis of leaves and fruits on Chaenomeles samples with the symptoms of phytopathogen lesions and phytophagous damage, was carried out in field conditions. The identification of fungi was performed by standard methods [11].

The arthropods specific composition (Arthropoda) was determined by damages, larvae and imago $[4,5]$.

\section{Results and discussion}

The breeding of Chaenomeles has been realized on the base of Michurinsk Agrarian University in the Tambov region since 2003.

\footnotetext{
* Corresponding author: shla-svetlana@ yandex.ru
} 


\subsection{The stability of the Russian cultivars of Chaenomeles}

New varieties Flagman, Voshod, Sharm, Michurinsky Vitamin, Alur and Albatros have flowers of original color, the corolla diameter of 3.5-5.8 cm, and their shoots are without spikes (Table 1). They were entered in the State register of the Russian Federation.

Table 1. Characteristics of Chaenomeles cvs.

\begin{tabular}{|l|c|c|c|c|c|}
\hline Cultivar & $\begin{array}{c}\text { Bush } \\
\text { average } \\
\text { height, } \\
\mathrm{cm}\end{array}$ & $\begin{array}{c}\text { Corolla } \\
\text { color }\end{array}$ & $\begin{array}{c}\text { Corolla } \\
\text { average } \\
\text { diameter, } \\
\mathrm{mm}\end{array}$ & $\begin{array}{c}\text { Fruits } \\
\text { average } \\
\text { diameter, } \\
\mathrm{mm}\end{array}$ & $\begin{array}{c}\text { Pericarp } \\
\text { average } \\
\text { thickness, } \\
\mathrm{mm}\end{array}$ \\
\hline Voshod & 90 & pale & 43 & 50 & 19 \\
\hline Flagman & 40 & $\begin{array}{c}\text { bright- } \\
\text { raspberry }\end{array}$ & 35 & 50 & 20 \\
\hline Sharm & 70 & $\begin{array}{c}\text { light- } \\
\text { orange }\end{array}$ & 40 & 48 & 15 \\
\hline $\begin{array}{l}\text { Michurins } \\
\text { ky Vitamin }\end{array}$ & 65 & $\begin{array}{c}\text { orange- } \\
\text { cream }\end{array}$ & 45 & 42 & 20 \\
\hline Allur & 80 & orange & 58 & 55 & 18 \\
\hline Albatros & 70 & white & 38 & 45 & 14 \\
\hline
\end{tabular}

The selected forms and varieties of Chaenomeles, tested in the Tambov region for the resistance to endophytic microflora, showed their high degree of plant viability [9]. The bacterial microbiota prevailed and varied greatly. The fungal microflora was less abundant during the testing and was represented by the species of genera Alternaria sp. (Fig. 1), Penicillium sp., Stemfillium sp., Cladosporium sp. and Fusarium sp. The long-term monitoring of 6 Chaenomeles cultivars in the Michurin breeding under field conditions revealed 4 types of phytopathogens with a minimal degree of plant susceptibility (Table 2).

Septoria cydoniicola Thüm was most often recorded on Chaenomeles cultivars. At the beginning of summer, numerous whitish-gray round spots with dark rims are formed on the leaves. The cultivars were diseaseaffected at 1 point, but the most resistant cultivar is Voshod.

The drying and premature falling of leaves having brown spots with light middles are caused by Phyllosticta cydoniae var. cydoniicola (Allesch.) Cif Phyllostictaceae). Entomosporiosis, the causative agents of which are Entomosporium eriobotryae S.Takim. and Diplocarpon mespili (Sorauer) B.Sutton, syn. Entomosporium maculatum f. maculatum Lev., identified in the cultivar Albatros (1 point), can also be a cause of the appearance of brown spots.

More seldom, Alternaria alternata (Fr.) Keissl (Pleosporaceae) was encountered in Chaenomeles cultivars at the end of spring. Small rounded dark brown spots with dark purple-red borders are visible on the leaves; later the spots merge. Heart-shaped rot appears in the course of the disease development. Cultivars Voshod, Sharm, Albatros and Michurinsky Vitamin are the most resistant to altarnariosis.

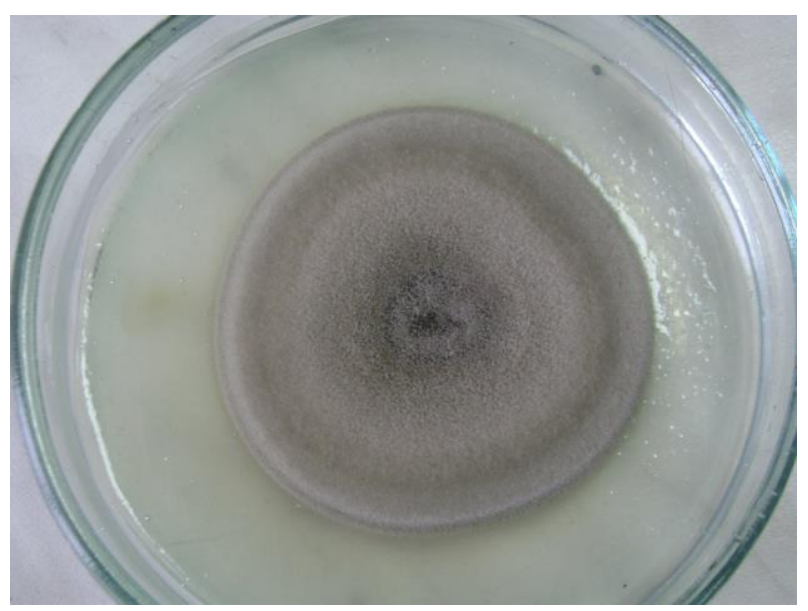

Fig. 1. Pure culture Alternaria sp. in a Petri dish on a wort nutrient medium. - Oder Fig. 1. Alternaria alternata on Chaenomeles leaves

Table 2. Affection of Chaenomeles cvs. by pathogenic microflora during 2010-2016, points

\begin{tabular}{|l|c|c|c|c|}
\hline $\begin{array}{c}\text { Cultivars and } \\
\text { forms }\end{array}$ & $\begin{array}{c}\text { Septoria } \\
\text { cydoniicola }\end{array}$ & $\begin{array}{c}\text { Alternaria } \\
\text { alternata }\end{array}$ & $\begin{array}{c}\text { Phyllosticta } \\
\text { cydoniae var. } \\
\text { cydoniaecola }\end{array}$ & $\begin{array}{c}\text { Diplocarpon } \\
\text { mespili }\end{array}$ \\
\hline Voshod & 0 & 0 & 1 & 0 \\
\hline Flagman & 1 & 1 & 0 & 0 \\
\hline Sharm & 1 & 0 & 0 & 0 \\
\hline $\begin{array}{l}\text { Michrinsky } \\
\text { Vitamin }\end{array}$ & 1 & 0 & 0 & 0 \\
\hline Allur & 1 & 1 & 1 & 0 \\
\hline Albatros & 1 & 0 & 0 & 1 \\
\hline
\end{tabular}

\subsection{Potentially dangerous microflora}

According to our observations, the pathogenic mycoflora on Chaenomeles plants is represented much wider and is capable of damaging leaves, flowers and fruits, causing the drying of branches and the death of entire bushes. Monilia fructigena, which affects $C h$. japonica and $C h$. cathayensis (2-3 points), is most often noted in the collection plantings in Moscow (SBG of RAS). Brownish-yellow pads of conidia sporification (Fig. 9) appear on the fruit surface during the disease development. Later, the fruit loses its taste and nutritional qualities, and its mummification comes. $M$. cydoniae Schell., from which leaves, flowers and ovaries fall off in summer, can be the causative agent of moniliosis. Old Ch. japonica bushes are affected at 2 points.

As a result of quince anthracnose, the causative agent of Gloeosporium cydoniae Mont. (Dermateaceae) dark brown spots appear (3 points) on the leaves of $C h$. japonica. Premature yellowing and leaf fall (2-3 points) are caused by Pestalotia breviseta Sacc. To a lesser extent (1 point), the fruit crop is affected by Phyllosticta velata Bubák.

The following diseases are often encountered (1-2 points) on old Chaenomeles bushes. Quince cytosporosis, that makes shrub branches shrink, is the causative agent of Cytospora cydoniae Bubák \& Kabát. (Valsaceae). Tubercular necrosis is the causative agent of Nectria cinnabarina Fr. (Nectriaceae). It begins with the bark necrosis on the shoots and branches, but leads to 
the death of entire plants. European cancer, caused by Neonectria galligena (Bres.) Rossman \& Samuels, syn. Nectria galligena Bres. (Nectriaceae), is found rarely; it causes the death of leaves, fruits and whole branches. Black quince cancer, caused by Sphaeropsis cydoniae Cooke \& Ellis (Aplosporellaceae), damages the fruits of Ch. japonica and Ch. Cathayensis. It leads to cracking and drying of branches bark.

Part of the Chaenomeles harvest may be lost (1-2 points) as a result of botrytiosis, penicillosis and fomopsis, which are noticeably manifested during the storage of fruits. Botrytiosis, which is found everywhere, caused by Botrytis cinerea (Sclerotiniaceae), affects Chaehenomeles flowers and fruits. First, brown spots with clear reddish edges appear. Then the fruits rot and prematurely fall. The rotting of fallen fruits is accelerated by the contact with soil, since Penicillium expansum Link and $P$. cyclopium Westling (Trichomaceae) penetrate their surface. Phomopsis is caused by pathogens Phomopsis mali Roberts, Ph. perniciosa Grove and Ph. ambigua (Nitschke) Traverso (Diaporthaceae) and is accompanied by dark brown spots on the leaves, leaf fall and rotting of Chaenomeles fruits.

The single tomato annular blotch virus (ToRSV), the symptoms of which are expressed in the form of chlorosis, wrinkling and necrotic leaf blotch with a characteristic alternation of dark and light areas, was observed on Chaenomeles fruits.

\subsection{Damaging entomofauna complex}

A complex of entomofauna representatives was revealed on Chaenomeles plants in the regions of central Russia (Table3). It should be noted that almost all groups of Insecta are rare and in a single amount ( $\geq 1$ point), with the exception of colony-forming aphids (1-2 points).

The most dangerous are migrating species Aphis fabae, which are black insects, and the non-migrating species A. pomi (Homoptera: Aphididae), which is common on Rosaceae fruit crops. Although they are not observed in Chaenomeles every year, these insects are carriers of viral diseases. The polyphage Palomena prasina (Homoptera: Pentatomidae) and Edwardsiana rosae L. (Homoptera: Cicadellidae), the phytophage of fam. Rosaceae, were pointed out in the complex of sucking species of the Moscow region.

The polyphagous bug Acanthosoma haemorrhoidalis L. (Hemiptera: Acanthosomatidae), usually feeding on deciduous cultures of the families Rosaceae, Betulaceae, Salicaceae, Tiliaceae, etc., was found in both regions. Gnawing phyllophages are diverse, although they appear sporadically. But they are capable of worsening the decorative appearance of a bush. The gray-green caterpillar Cladius pallipes Lep., Syn. Priophorus padi L. (Hymenoptera: Tenthredinidae), capable of skeletonizing Chaenomeles leaves, is especially active at the beginning of summer. Archips variegana Schiff. and A. rosana L., syn. Ccoecia rosana L., feeding on deciduous plants, including those from the Rosaceae family, are noticeable out of leafworms (Lepidoptera:
Torticidae). The second type not only turns leaves into a tube, cigar-shaped or lumpy, but also damages ovaries and fruits, gnawing holes in the pulp to the seed chamber.

An especially active development of caterpillars Acleris variegana Den. et Schiff. was noticed in 2016 in the Tambov region on the Albatross cultivar, when they were eating out fruit buds and buds, skeletizing the leaves and wrapping them into a bundle of cobwebs. Green brown head caterpillar Exapate congelatella $\mathrm{Cl}$. also gnaws into the buds and leaves, forming a lump. The small wormhole, the crenellate lunate Ancylis selenana Gn., common on Rosaceae fruit crops, was noted during the monitoring on Ch. japonica in the arboretum of the MBG RAS on Ch. $\times$ superba (1-2 points). Greenish-yellow caterpillars (up to $1 \mathrm{~cm}$ long) skeletonize leaves, fold them in half along the central vein and, then, they gnaw them.

Table 3. Occurrence of entomofauna representatives in Central Russia

\begin{tabular}{|l|l|l|}
\hline \multicolumn{1}{|c|}{ Insecta } & \multicolumn{1}{|c|}{ Moscow region } & Tambov region \\
\hline Homoptera & $\begin{array}{l}\text { Aphis fabae, A. pomi, } \\
\text { Palomena prasina, } \\
\text { Edwardsiana rosae }\end{array}$ & Aphis fabae \\
\hline Hemiptera & $\begin{array}{l}\text { Acanthosoma } \\
\text { haemorrhoidalis }\end{array}$ & $\begin{array}{l}\text { Acanthosoma } \\
\text { haemorrhoidalis }\end{array}$ \\
\hline Hymenoptera & $\begin{array}{l}\text { Cladius pallipes, } \\
\text { Hoplocampa testudinea, } \\
\text { Vespa crabro }\end{array}$ & \\
\hline Eepidoptera & $\begin{array}{l}\text { Nepticula malella, } \\
\text { Stigmella pomella } \\
\text { Archips variegana, A. } \\
\text { rosana, Laspeyresia } \\
\text { pomonella, Exapate } \\
\text { congelatella, Ancylis } \\
\text { selenana, Diloba } \\
\text { coeruleocephala }\end{array}$ & $\begin{array}{l}\text { Acleris } \\
\text { variegana, } \\
\text { Exapate } \\
\text { congelatella, } \\
\text { Stigmella } \\
\text { pomella }\end{array}$ \\
\hline Coleoptera & $\begin{array}{l}\text { Rhynchites bacchus, } \\
\text { Coenorrhinus pauxillus, } \\
\text { Phyllobius urticae, } \\
\text { Agriotes obscurus }\end{array}$ & $\begin{array}{l}\text { Rhynchites } \\
\text { bacchus, } \\
\text { Coenorhinus } \\
\text { pauxillus, } \\
\text { Otiorrhynchus } \\
\text { ligustici }\end{array}$ \\
\hline
\end{tabular}

The gnawing phytophages of Chaenomeles include the blue-headed scoop Diloba coeruleocephala L., syn. Episema coeruleocephala L. (Lepidoptera: Noctuidae) and alfalfa skosar Otiorrhynchus ligustici L. (Coleoptera: Curculionidae), which feeds on buds and gnaws young leaves.

The beetle Agriotes obscurus L. (Coleoptera: Elateridae), that usually prefers cereal leaves, is found on Chaenomeles fruits,; small beetle Phyllobius urticae Deg., syn. Phyllobius pomaceus Gyllenhal (Coleoptera: Curculionidae) is a polyphage found on this plant of the families of Urticaceae and Rosaceae.

Nepticula malella Stainton (syn. Stigmella malella Stt.), leaving serpentine mines extended in the middle, is marked among mining phyllophages; Stigmella pomella Vaugh. (Lepidoptera: Nepticulidae) has characteristic thin mines.

Chaenomeles fruits can damage several carpophages typical of the Rosaceae family. Rhynchites bacchus L. 
and Coenorrhinus pauxillus Germ, consuming young leaves and flowers of Chaenomeles, are found everywhere. (Coleoptera: Rhynchitidae),. The caterpillar Laspeyresia pomonella L., syn. Carpocapsa pomonella L. (Lepidoptera: Torticidae), gnawing a ripe fruit, is seldom noticed.

The seed chambers in the fruits of Ch. japonica are destroyed by Hoplocampa testudinea Clug. (Hymenoptera: Tenthredinidae) frequently observed on apple trees. European hornet - Vespa crabro L. (Hymenoptera: Vespidae) usually feeds on the nectar of flowers, juice and fruit pulp. Adults eat the flesh of ripe Chaenomeles fruits, and that accelerates their rotting.

\section{Conclusion}

Many years have been spent to implement the systematic monitoring of pathogens and phytophages on plants $C h$. japonica, Ch. cathayensis, Ch. $\times$ superba and multipurpose varieties in central Russia. Among the identified pathogens, the most harmful pathogens are Alternaria alternata, Septoria cydoniicola, Entomosporium eriobotryae, Phyllosticta cydoniae var. cydoniicola, Diplocarpon mespili, Gloeosporium cydoniae, Monilia cydoniae, M. fructigena; smaller Pestalotia breviseta and Phyllosticta velata, Penicillium expansum and $P$. cyclopium. Filoplan mushrooms are widely spread.

With age, the increase in the infectious background and the accumulation of damaging phytophages (Botrytis cinerea, Phomopsis mali, Ph. Perniciosa and Ph. ambigua), including the viral disease (ToRSV), are noticed in plantings. Cytospora cydoniae, Sphaeropsis cydoniae, Nectria cinnabarina and Neonectria galligena, causing the drying of branches and death of entire bushes, are marked on country-age plantings. Chaenomeles plants have a complex of sucking, gnawing and mining phytophages. The following gnawing insects prevail among entomofauna representatives: phyllophagous - Archips variegana, A. rosana, Acleris variegana, Exapate congelatella, Cladius pallipes, Ancylis selenana, Diloba coeruleocephala, Agriotes obscurus, Phyllobius urticae, Otiorrhynchus ligustici, and also carpophages - Rhynchites bacchus, Coenorrhinus pauxillus, Laspeyresia pomonella, Hoplocampa testudinea, Vespa crabro. Sucking insects (Palomena prasina, Edwardsiana rosae, Acanthosoma haemorrhoidalis) are dangerous, especially Aphis fabae and pomi, which are carriers of phytoviruses. Phytophage miners (Nepticula malella and Stigmella pomella) are few in number and have almost no effect on the decorativeness of bushes. Cochlea-in stonemason Helicigona lapicida L. (Gastropoda: Helicidae), that feeds on leaves and, less often, fruits in dense plantings, is seldom observed on Ch. Japonica plants.

The analysis of phytophages composition shows that these are mainly autochthonous species, both polyphages and oligophages, preferring plants of the Rosaceae family. Probably, this set is due to the close proximity of the experimental Chaenomeles plants with the plantings of Rosaceae family fruit crops, and it facilitates the expansion of food links and favors the creation of new potentially dangerous "introduced species-pathogen" complexes.

\section{Acknowledgements}

The work was carried out as part of the state assignment of State Biological Standard of the Russian Academy of Sciences "Biological diversity of natural and cultural flora: fundamental and applied issues of study and conservation" (No. 118021490111-5).

The authors of the present article would like to express their gratitude for organizing this research and the necessary assistance in the material identification in the Michurinsk city of the Tambov region to L.P. Petrishcheva and M.K. Skripnikova; in Moscow to O.B. Tkachenko, L.Yu. Treivas, S.L. Rysin and I.A. Kozlova.

\section{References}

1. L.P. Garkava, K. Rumpunen, I.V. Bartish, Genetic Relationships in Chaenomeles (Rosaceae) revealed by isozyme analysis, Scientia Horticulturae, 85(1-2), 21-35 (2000)

2. I. Norin, K. Rumpunen, Japanese Quince Potential Fruit Grop for Northern Europe, Pathogens on Japanese Quince (Chenomeles japonica) Plants, 37-54 (2002)

3. K. Rumpunen, Reprinted from: Trends in new crops and new uses, Chaenomeles: Potential New Fruit Crop for Northern Europe, 385-392 (2002)

4. E.V. Isaeva, Z.A. Shestopal, Atlas of diseas. of fruit and berry crops, 144 (1991)

5. P.P. Savkovsky, Atlas of pests of fruit and berry crops, 103 (1990)

6. L.D. Komar-Dark, New breeding forms of henomeles, New and non-traditional plants and prospects for their use, 11, 314-317 (2015)

7. A.G. Kuklina, V.N. Sorokopudov, I.A. Navalneva, Integral assessment of the fruiting of selected forms of henomeles (Chaenomeles Lindl.) In Central Russia, Proc. of higher educational institutions. Volga region. Natural Sciences, 2(14), 3-10 (2016)

8. N.N. Saveliev, Yu.A. Fedulova, M.K. Skripnikova, Chaenomeles is a promising high-vitamin fruit culture, Bull. of the Russ. Acad. of Agricult. Sci., 3, 62-63 (2009)

9. L. Yu, J.K. Bai, New species of Phoma and Phyllosticta from China, Acta Myc. Sin., 14, 192-195 (1995)

10. K. Madachi, A. Sahragard, Comparative life table of Aphis pomi (Hemiptera: Aphididae) on Malus pumila L. and Chaenomeles japonica under laboratory conditions, J. Crop Prot., 1(4), 321-330 (2012)

11. M.K. Khokhryakov, V.I. Potlaychuk, Determinant of crop diseases, 304 (1984) 